\title{
Improving Blood Protein and Albumin Level Using Dried Probiotic Yogurt in Broiler Chicken
}

\author{
Lovita Adriani ${ }^{1, *}$, Andi Mushawwir ${ }^{1}$, Chitra Kumalasari ${ }^{1}$, Leni Nurlaeni ${ }^{1}$ Ronny \\ Lesmana $^{2}$, Urip Rosani ${ }^{1}$
}

${ }^{1}$ Department of Animal Nutrition and Feed Technology, Faculty of Animal Husbandry, Universitas Padjadjaran, 45363, Indonesia; ${ }^{2}$ Departement of Biomedical Science, Faculty of Medicine, Universitas Padjadjaran , 45363, Indonesia

Received: March 12, 2021; Revised: May 17, 2021; Accepted: September 28, 2021

\begin{abstract}
Dried probiotics have a good effect on the digestive tract in inhibiting the growth of pathogenic bacteria and increasing the blood protein content. This study aims to identify the effect of dry probiotics on protein and blood albumin levels in broiler chickens. In the experiment, a Completely Randomized Design (CRD) consisting of five treatments and 4 replications was applied. The probiotic treatments included T0: basal ration (BR); T1: basal ration with dry probiotic A (100\% fermented cow's milk/FCM); T2 : basal ration with dry probiotic B (fermented cow's milk/FCM and fermented mung bean milk/FMBM, with a composition of 75\% : 25\%), T3: basal ration with dry probiotic C (fermented cow's milk/FCM and fermented soy milk/ FCM, with a composition of 75\% and 24\%); and T4: basal ration with dry probiotic D (consisting of fermented cow's milk/FCM, fermented mung bean milk/FMBM and fermented soy milk/FSM, with compositions: 50\%, $25 \%$ and $25 \%$, respectively). The results showed that the difference in blood protein and albumin levels $(P>0.05)$ was not significant. Dried probiotics tend to increase blood protein and albumin and have the potential to correlate with protein anabolism and broiler performance.
\end{abstract}

Keywords: dried probiotic, oven-dry, blood protein, albumin, broiler chicken

\section{Introduction}

Broilers in the form of poultry are used as meat producers and are widely consumed. The quality and consumer expectations of good broiler meat are weight and muscle contours. Weight gain is influenced by the amount of protein contained in the ration (high protein content plays a role in weight gain) (Saleh and Dwi, 2005). Broiler chicken feed must pay attention to the balance of energy and protein contained in the ration. Broiler chicken ration is an additional feed to optimize shelf life and increase efficiency during rearing. However, the side effects of feed additives can bring some health problems. Thus, probiotics are alternative feed additives that can improve livestock health, especially improving the digestive tract ecosystem through microflora balance. Administration of probiotics from an early period improves the balance of intestinal microbes (Adriani et al., 2019).

Blood proteins in plasma are albumin, globulin, and fibrinogen (Ganong, 2000). Total protein examination serves as an examination of health status by looking at changes in protein levels that occur. The protein profile in blood serum shows protein deposition, because if protein and albumin are high, the probability of protein deposition in meat is higher. Albumin is the main protein contained in blood plasma which is responsible for osmotic pressure and as a transport agent for various small molecules in the blood such as fatty acids and bile pigments (Mushawwir and Latipudin, 2011). Probiotics increase ration efficiency, egg production, and lower egg cholesterol and serum cholesterol levels. In addition, probiotics are also able to reduce non-protein nitrogen in the blood, concentrations of uric acid, ammonia and urea in the blood (Rusmana, and Adriani, 2020).

The experiment in this study was conducted to assess the impact of dry probiotics on several blood biochemical parameters, including blood protein and broiler albumin. The use of probiotics in combination with mung bean milk, FCM, and FSM has not been widely reported by previous researchers; therefore, this study studied the biochemical profile of broiler blood given dry probiotics. Previous studies have shown that the phenol content and antioxidant activity of fermented products appear to increase. This phenomenon is caused by the mobilization of the phenolic conjugate form during the fermentation activity (Xiao et al., 2015). Another study reported that microbes belonging to the lactate group were able to produce enzymes. One type of enzyme that is synthesized during the fermentation process is an enzyme that breaks down carbohydrates. This phenomenon is characterized by the release of phenolic compounds (Razak et al., 2015). In addition, it can reduce anti-nutrition (Susi, 2012).

Some researchers use liquid or dry yogurt with the dry fries method. However, in this study, drying was carried out using a simple technology at a very low cost to reduce

\footnotetext{
* Corresponding author e-mail: teddyhidayatconf@gmail.com.
} 
feed prices. The result of drying probiotics produces low microbiota than liquid form. However, dried probiotics have beneficial because produce high lactic acid, bacteriocin, and several compounds from soybeans and mung beans (Lengkey and Adriani, 2009; Adriani et.al., 2015).

\section{Materials and Methods}

\subsection{Materials}

The materials used in this study consisted of Cow's milk (CM), soybean, mung bean, and the starter contains several types of bacteria, namely Streptococcus thermophilus, Lactobacillus bulgaricus, Bifidobacterium bifidum, Lactobacillus acidophilus, maltodextrin DE 1012, spectrophotometer, and several blood biochemical kits. (Biolabo, Bandung).

\subsection{Methods}

\subsubsection{Experiment method}

A total of 100 broiler DOC, 5 days old used in this investigation. This feeding treatment was carried out for 30 days study, accompanied by the physical recording of the environment and blood sampling. Giving dry probiotics was done by adding them to the ration. The dose of dry probiotics mixed into the ration was $2 \%$ of the total basal ration. A completely randomized design was used in this experiment, consisting of four treatments and five replications. The treatments include T0: BR; T1: BR with dried probiotic A (100\% FCM); T2: BR with dried probiotic B (FCM and FMBM, with composition 75\%: 25\%), T3: BR with dried probiotic C (FCM and FSM, with composition $75 \%$ and $24 \%$ ); and $\mathrm{T} 4$ : BR with dried probiotics D (consisting of FCM, FMBM and FSM, with a composition, each: 50\%; 25\% and 25\%).

\subsubsection{Processing of probiotics}

The basic ingredients used for fermentation in this experiment have been soy milk, CM, and green bean milk. The microbes that have been added to this fermentation process are Streptococcus thermophilus, Lactobacillus bulgaricus, Bifidobacterium bifidum and Lactobacillus acidophilus. Fermented milk mixed with 10-12 5\% DE maltodextrin, serves as a nutritional supplement for microorganisms. Furthermore, probiotics were dried for 25 hours using an oven (simple method) at a temperature of $40^{\circ} \mathrm{C}$.

\subsubsection{Detection Method}

Blood sampling through the external pectoralis vein using a $5 \mathrm{~mL}$ EDTA tube was performed randomly on 20 broilers (consisting of 5 birds per replication, and treatment of 4 birds per replication). Blood plasma samples were analyzed according to the kit protocol (Biolabo, France). The absorbance of the sample was determined using a spectrophotometer at the Laboratory of Animal Physiology and Biochemistry, University of Padjadjaran. The blood biochemistry observed included total protein and albumin in blood plasma. Blood samples were taken when the chickens were 2 and 4 weeks old as much as $3 \mathrm{ml}$. using a syringe containing EDTA, then the plasma is separated for further analysis. Analysis of total protein and albumin used a spectrophotometer.

\subsubsection{Data Statistical analysis}

The data of plasma protein and albumin were analyzed using the variance of one-way analysis method. The significant difference between feed treatments was determined by Tukey's analysis with the degree of significant difference at $\mathrm{P}<0.05$. As a basis for statistical analysis, the hypothesis has been established that dry probiotic levels can increase blood protein and albumin levels in broiler chickens.

\section{Results and Discussion}

Table 1. Effect Dried Probiotic on Blood Protein and Albumin Broiler Chicken

\begin{tabular}{lllllll}
\hline Variable & $\mathrm{T} 0$ & $\mathrm{~T} 1$ & $\mathrm{~T} 2$ & $\mathrm{~T} 3$ & $\mathrm{~T} 4$ & $\mathrm{p}$-value \\
\hline Blood & $2.52 \pm$ & $2.59 \pm$ & $3.22 \pm$ & $2.60 \pm$ & $2.81 \pm$ & $0.074 ;$ \\
$\begin{array}{l}\text { Protein } \\
\text { (g/dl) }\end{array}$ & 0.20 & 0.85 & 0.47 & $2-0.12$ & 0.51 & $\mathrm{n}=100$ \\
$\begin{array}{l}\text { Albumin } \\
\text { (g/dl) }\end{array}$ & $1.30 \pm$ & $1.36 \pm$ & $1.44 \pm$ & $1.32 \pm$ & $1.38 \pm$ & $0.062 ;$ \\
& 0.36 & 0.66 & 0.91 & 0.35 & 0.51 & $\mathrm{n}=100$
\end{tabular}

The results showed that the administration of dry probiotics had no significant effect on increasing blood protein and albumin $(\mathrm{P}>0.05)$. Although there was no significant difference, blood protein and albumin levels increased by $21.74 \%$ and $10.77 \%$ at T2 (FCM + FMBM dry probiotic mixture, with a ratio of $75 \%$ : $25 \%$ ). Sugiharto et al. (2017) showed that the normal range of blood protein ranges from 2.14 to $3.12 \mathrm{~g} / \mathrm{dl}$. Analysis of variance showed that dry probiotic feeding showed no significant difference ( $\mathrm{P}>0.05)$. The results of the current investigation seem to agree with the findings of Djouvinov et al. (2005), and Aluwong et al. (2012) who found that probiotic supplementation did not affect protein and total albumin levels in chickens. Although not significantly different, there is a tendency to increase protein levels in the blood. Based on previous research, Arslan and Saatci (2004) and El-Rahman et al. (2012) showed an increase in plasma protein concentration with the addition of probiotics in the diet. The high protein content in the blood indicates that the protein deposition in the meat is also high; on the contrary, the low protein value in the blood or below the standard indicates that the chicken lacks nutrition. Optimal liver function will be followed by an increase in plasma protein because most plasma proteins are synthesized in the liver (Widhyari., et al. 2014). Previous studies have also shown that plasma protein can be a valid indicator in determining the status of tissue function (Mushawwir, A et al, 2020; Tanuwiria and Mushawhir, 2020. This is related to the function of liver tissue as a producer of albumin protein. It is known that $75 \%$ of plasma protein blood is albumin. 


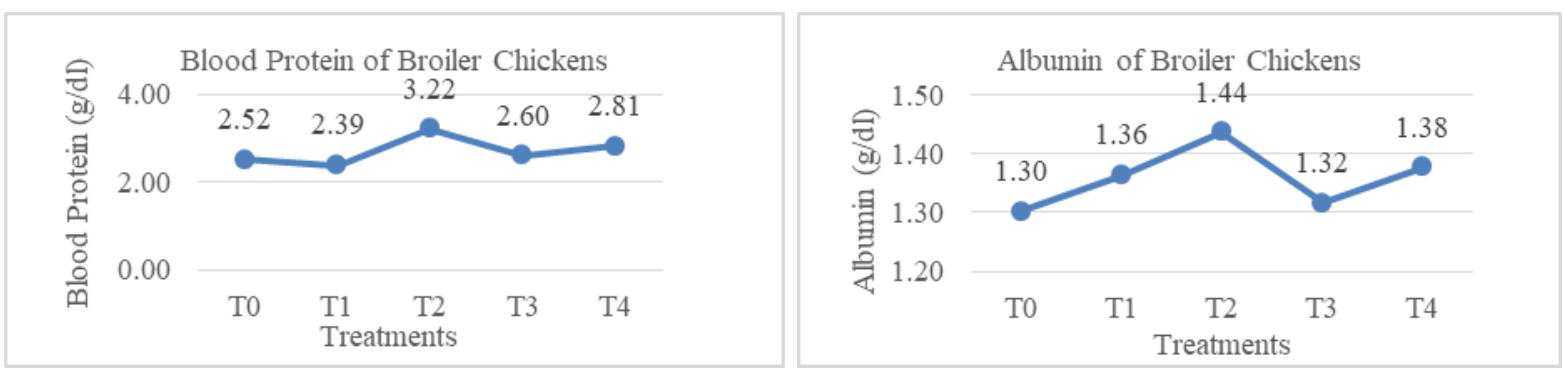

Figure 1. Effect Dried Probiotic on Blood Protein and Albumin Broiler Chicken

The average albumin for each treatment (Table 1) ranges from 1.30-1.44 g/dl. Blood albumin levels from lowest to highest include T0: $1.30 \mathrm{~g} / \mathrm{dl}, \mathrm{T} 3: 1.32 \mathrm{~g} / \mathrm{dl}, \mathrm{T} 2$ : $1.36 \mathrm{~g} / \mathrm{dl}$, T4: $1.38 \mathrm{~g} / \mathrm{dl}$, and T2: $1.44 \mathrm{~g} / \mathrm{dl}$. Blood albumin in the study is in the normal range about $1.06-1.39 \mathrm{~g} / \mathrm{dl}$ (Owo Sibo et al., 2013). The variance analysis results showed that supplementation of dry probiotics did not show a significant difference ( $\mathrm{P}>0.05)$. However, there is a tendency to increase blood albumin levels.

Albumin and blood protein plays a major role in the deposition of protein into the meat. In accordance with Liu et al. (2015) which states that albumin affects the growth rate of broiler chicken. It means low albumin will have an effect on total protein. Consumption of less protein causes reduced blood albumin so that protein deposition into the meat will also decrease. Parmentier et al. (2009) and Savary-Auzeloux et al., (2010) reported that blood albumin produced in the liver forms the majority of all plasma proteins (consisting of $60 \%$ albumin). The content of blood protein values is normally used for weight gain (Saleh and Dwi, 2005). Blood protein and albumin were highest in T2 with dry probiotics combined with $75 \%$ FCM and 25\% FSM. Probiotics in the ration increase the content of lysine analogue and aminoethyl cysteine in the digestive tract which is converted to amino acid lysine and cysteine so as to increase the retention of proteins that play a role in meat formation (Candrasih and Bidura. 2001; Farhana et al., 2012; Saikat et al., 2017).

One of the causes of weight gain in living things is the activity of probiotic bacteria. Previous researchers reported that the increase in digestive efficiency is caused by the use of nutrients and absorption of nutrients by absorptive cells (Lengkey and Adriani, 2011; Sheval et al., 2020). The results of previous studies showed that an increase in digestive enzyme activity and an increase in the morphometric surface of intestinal villi occurred due to the presence of probiotic bacteria (Muhannad et al., 2019). This physiological condition also has an impact on increasing digestibility, absorption of nutrients, as well as the formation and increase in the size of new tissues (Lengkey and Adriani, 2011; Priastoto et al., 2016; Adriani et al., 2019). The results of the same study have also been reported by other researchers (Hernawan et al., 2017; Mushawwir et al., 2018; Adriani and Mushawwir, 2020). An increase in the number and width of the jejunal villi from feed plus probiotics that affect the final body weight of broilers has also been reported by Adriani et al. (2019). In addition, several researchers, including Toghyani et al., (2015), Astuti (2015), Jin et al., (2000) emphasized that increasing the population of microbes that are beneficial to livestock will prevent the development of pathogenic microbes in the digestive tract of food.

\section{Conclusion}

Dried probiotics can increase protein in the blood by $27.77 \%$, and albumin by $10.76 \%$ compared to control, in the FCM + FMBM mixture treatment by $75 \%$ and $25 \%$, respectively. Although all treatments were able to increase blood protein and albumin, the results of increasing levels were not significantly different in broiler chickens. Interestingly, the increase in plasma protein and albumin may be a valid indication of increased protein anabolism and overall broiler performance.

\section{Significant statement}

This study found that the application of FCM, FMBM and FSM as probiotics added to broiler feed was beneficial for increasing blood protein and albumin in plasma. The results of this study have helped researchers to explore more deeply the effect of various combinations of FCM, FSM, and FMBM as probiotics to increase protein metabolism in supporting the immune and performance of broiler chickens. Thus, the new theory about the application technique and the impact of using FCM, FMBM and FSM in broiler rations can be accepted.

\section{Acknowledgments}

This work is supported by the PTUPT project from the Ministry of RISTEK-DIKTI Grant 2020, as well as the Academic Leadership Grant from Padjadjaran University for Lovita Adriani (2020). Therefore, we give the award to both parties.

\section{References}

Adriani L, Widjastuti T, and Dermawan R. 2015. The effect of probiotic supplemented ration on broiler abdominal fatty content and final weight. Lucrari Stiintifice Zeria Sohteniee., 53 (2): 2225.

Adriani, L., Latipudin D, Balia RL, and Widjastuti T. 2019. Improvement of Small Intestine Morphometry in Broiler Chicken Using Fermented Cow and Soymilk as Probiotic. International $J$ Pakistan Sci., 18 (8): 255-259.

Adriani L, and Mushawwir A. 2020. Correlation Between Blood Parameters, Physiological and Liver Gene Expression Levels in Native Laying Hens Under Heat Stress. IOP Conf. Series: Earth Env Sci, 466:1-7

Aluwong, T, MA. Raji, BF. Hassan, MU. Kawu, P. Kobo, JO. Iaand Ayo. 2012. Effect of Different Levels of Supplemental Yeast on Performance Indices and Serum Biochemistry of Broiler Chickens. The Open Conference Proceedings Journal., 3: 41-45. 
Arslan C, and Saatci M. 2004. Effects of probiotic administration either as feed additive or by drinking water on performance and blood parameters of Japanese quail. Arch Geflügelkd., 68: 160163.

Astuti. 2015. Utilization of Lactic Acid Bacteria Probiotics from Fish Digestion Channels on Growth and Cholesterol Levels of Broiler Chicken Meat. J Sci Technol Res, 20 : 2.

Candrasih NNK, and Bidura IGNG. 2001. The Effect of Use of Cocoa Shells Supplemented with Yeast Tape in the Ration on the Appearance of Bali Ducks. Animal Husb Sci Mag., 4 (3): 67-72.

Djouvinov D, Svetlana B, Tsvetomira S, and Tatiana V. 2005. Effect of Feeding Lactina Probiotic on Performance, Some Blood Parameters and Caecalmicroflora of Mule Ducklings. Trakia $J$ Sci, 3: 22-28.

El-Rahman, AHA., HH. Kamel, WM. Ahmed, OSH. Mogoda, and AH. Mohamed. 2012. Effect of Bactocell® and Revitilyteplustm as probiotic food supplements on the growth performance, hematological, biochemical parameters and humoral immune response of broiler chickens. World Appl Sci J, 18 (12): 305-316.

Farhana SD, Khondoker MH, Azim MA, and Moinul HMd. 2012 Isolation, Characterization and Determination of Antimicrobial Properties of Lactic Acid Bacteria from Human Milk. Jordan J Biol Sci, 6 (2) : 111- 116

Ganong WF. 2000. Medical Physiology, Medical Book Publisher EGC, Jakarta.

Hernawan, E, Adriani L, Mushawwir A, Cahyani C, and Darwis D. 2017. Effect of dietary supplementation of chitosan on blood biochemical profile of laying hens. Pakistan J Nut,16 (9):696-699.

Jin, LZ, Ho YW, Abdullah N, and Jalaludin S. 2000. Digestive and bacterial enzyme activities in broilers fed diets supplemented with Lactobacillus cultures. Poul. Sci, 79: 886-891.

Massadehd IM, and Mhmoud S. 2019. Antibacterial Activities of Soil Bacteria Isolated from Hashemite University Area in Jordan. Jordan J Biol Sci, 12 (4) : 503 - 511.

Mushawwir A, and Latipudin D. 2011. Some biochemical parameters of the laying hens of grower and layer layers in the "upper zonathermoneutral" environment. J Indonesian Animal Husb, 13 (3): 191 - 198.

Mushawwir A, Tanuwiria UH, Kurnia AK, Adriani L, Wiradimadja R, and Suwarno N. 2018. Evaluation of Haematological Responses and Blood Biochemical Parameters of Heat-stressed Broilers with Dietary Supplementation of Javanese Ginger Powder (Curcuma xanthorrhiza) and Garlic Extract (Allium sativum). Int J Poultry Sci., 17:452-458.

Mushawwir, A, Arifin J, Darwis D, Puspitasari T, Pengerteni DS, NuryanthiN, and Permana R. 2020. Liver metabolic activities of Pasundan cattle induced by irradiated chitosan. Biodiversitas., 21 (12):5571-5578

Lelamurni LAR, Nur YAR, Anisah J, Shaiful AS, Kamariah L, 2015. Enhancement of phenolic acid content and antioxidant activity of rice bran fermented with Rhizopus oligosporus and Monascus purpureus. Biocatalysis and Agricultural Biotechnology., 4 (1): 33-38.

Lengkey HAW and Adriani L. 2009. Effects of milk fermented with Lactobacillus acidophilus and Bifidobacterium spp., on lactic acid and acetic acid content and on Staphylococcus aureus and Pseudomonas aeruginosa. Biotechnology in Animal Husbandry., 25: $719-724$
Lengkey HAW and Adriani L. 2011. The Effect of Lactobacillus bulgaricus and Streptococcus thermophilus as Ration Supplement on Broiler Carcass Weight, Carcass Fat Content and The Serum Cholesterol Carcass Content. Int Sem Biotechnol.

Liu B, Pang Y, Bouhenni R, Duah E, Paruchuri S, and McDonald L. 2015. A Step Toward Simplified Detection of Serum Albumin on SDS-PAGE Using an Environment-Sensitive Flavone Sensor. Chem Comm, 51 (55) :11060-11063.

Owo sibo, AO., OM. Odetola, O. Odunsi, OO. Adejinmi, and OO. Lawrence-Azua. 2013. Growth, haematology and serum biochemistry of broilers fed probiotics based diets. J Academic., 8 (41): 5076 - 5081.

Parmentier HK, Rodenburg B, Reilingh GDV, Beerda B, and Kemp B. 2009. Does Enhancement of Spesific Immune Responses Predipose Laying Hens For Feater Pecking. Poultry Sci, 88: 536-542.

Priastoto D, Kurtini T, and Sumardi. 2016. The Effect of Probiotics from Local Microbes on Performance of Layer. Jurnal Ilmiah Peternakan Terpadu., 4(1): 80-85.

Rusmana D. and Adriani L, 2020. Effect of Fermented Cow and Soymilk as Probiotic on Energy Metabolism and Nutrient Retention in Broiler Chicken. Int J Poultry Sci, 19: 277-281.

Saleh, E. and J. Dwi. 2005. The Effect of Katuk Leaf Flour on Broiler Chicken Performance. Jurnal Agribisnis Peternakan., 1(1):14-16.

Saikat RP, Raad SMD, and Lukman HMD. 2017. Antibacterial Different Solvents. Jordan J Bio Sci, 10 (3) : 213 - 217.

Savary- Auzeloux, I., G. Kraft, BJ. Bequette, I. Papet, D. Remond, and I. Ortigues-Marty. 2010. Dietary Nitrogen-to-Energy Ratio Alters Amino Acid Partition in the Whole Body and Among The Splanchnic Tissues of Growing Rams. J Animal Sci, 88: 21222131.

Sheval FM , Qerim IS, Kasum RrL, and Isa RE. 2020. Chronic Effects of Lead Exposure on Oxidative Stress Biomarkers in Feral Pigeon (Columba livia) from Smelter Area in Kosovo. Jordan J Biol Sci, 13 (3) : 589 - 595.

Sugiharto S, Isroli Y, Endang W, and Fatan DP. 2017. Intestinal microbial ecology and hematological parameters of broiler fed cassava waste pulp fermented with Acremonium charticola. $J$ Vet World., 10 (3): 324 - 330.

Susi, S. 2012. Chemical Composition and Amino Acid Composition of Nagara Bean Tempe ((Vigna unguiculata ssp. cylindrica). Agroscientiae., 19(1): 28-36.

Tanuwiria, U.H. and Mushawwir A. 2020. Hematological and antioxidants responses of dairy cow fed with a combination of feed and duckweed (Lemna minor) as a mixture for improving milk biosynthesis. Biodiversitas., 21 (10) :4741-4746.

Toghyani, M, Mosavi SK, Modaresi M, and Landy N. 2015. Evaluation of kefir as a potential probiotic on growth performance, blood biochemistry and immune responses in broiler chicks. Animal Nut., 1(3) : 305-309.

Widhyari SD, Esfandiari A, dan Herlina. 2014. Profile of Total Protein, Albumin, and Globulin on Broiler were Given Turmeric, Garlic, and Zn. Indonesian Agr Sci J, 10(3):179-184.

Yu XL, Wang XW, Li X, Chen MJ, and Mingsheng D. 2015. Enhancement of the antioxidant capacity of soywhey by fermentation with Lactobacillus plantarum B1-6. J functional foods., 12(2) : 33-44. 